\title{
Assessing changes in surface water quality and pollutant load in Dong Nai province
}

\author{
- Thi Diem Huong Bui
}

Institute of Meteorology, Hydrology, Oceanology and Environment

- Ngoc Tuan Le*

University of Sciences, VNU- HCM

(Received on $17^{\text {th }}$ December 2015, Accepted on November $21^{\text {th }} 2016$ )

\begin{abstract}
This study aims at assessing changes in the surface water quality in Dong Nai province (20102014). In addtion, the pollutant loads of wastewater sources were calculated till 2020-2030 with 03 wastewater treatment scenarios serving for the local environmental management. The water quality index (WQI) showed the surface water quality of Dong Nai Province to be gradually improved during the dry season but significantly declined in the rainy season in the last 5 years due to high concentrations of suspended solids (SS), Fe and microorganism - especially in the $3^{\text {rd }}$ segment of Dong Nai river through Bien Hoa City. This
\end{abstract}

current status certainly relates to pollutant loads from waste water sources in the province. Pollutant loads of domestic and industrial wastewater in Bien Hoa city are the highest $40 \%$ per source), livestock activities in Xuan Loc district account for $20 \%$; aquaculture activities in Nhon Trach district contribute more than $75 \%$ of the corresponding total loads, etc. in which loads of BOD5, COD and SS are significant, about 581,570 tons, 1,035,403 tons and 639,153 tons per year, respectively, and tend to increase in the future, requiring appropriate solutions.

Keywords: pollutant load, surface water, water quality, water quality index

\section{INTRODUCTION}

According to Cooke et al. [1], surface water quality can be assessed through the pollutant loads and concentration. Previously, the river water quality is assessed through the concentration of individual pollutant compared to local standards, thence compared to general evaluation approaches through Water Quality Index (WQI) as NSF WQI (USA), Bhargava-WQI (India), CCME-WQI (Canada), etc. The related WQI researches and applications in Vietnam [2-5] are the basis for building suitable surface water quality model for the study area. In 2011, the General Department of Environment issued WQI calculations Handbook for using in Vietnam.

About pollutant loads, many studies have been implemented [6-8]. In Vietnam, the pollutant loads calculation is approached in two ways: (1) Rapid Assessment [9-11], (2) Based on specific concentration of waste sources $(\mathrm{C})$ and the waste flow (Q) [12-14].

The relationship between changes in surface water quality and pollutant loads is an important basis for planning the management measures, especially in Dong Nai province - one of the fastest growth localities in the Southeast of Viet Nam. Accordingly, this research focuses on assessing the changes in surface water quality in the main river (2010-2014) and calculating the pollutant loads which arise from natural and artificial waste sources $(2013,2020,2030)$ in Dong Nai province, thereby providing valuable scientific information to serve local surface water management, 
contributing positively in ensuring sustainable development and creating basis for further studies on water resources as calculating load capacity, etc.

\section{METHODS}

\section{Gathering data}

The monitoring data of surface water quality (2010-2014) from the Department of Natural Resources and Environment of Dong Nai province (Fig. 1), the pollutant emission coefficient, the local statistical figures and development plan, etc.

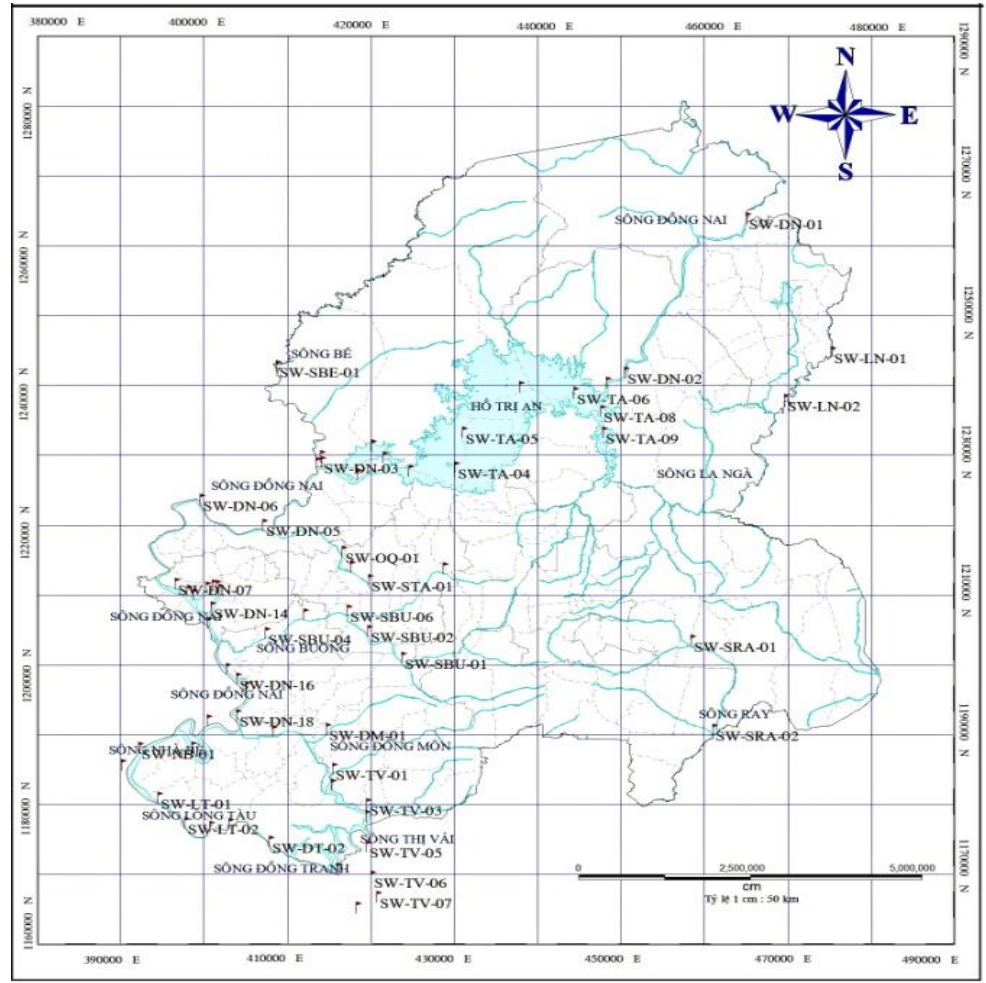

Fig. 1. Map location of monitoring stations on surface water quality of Dong Nai Province in 2014

\section{Investigating, actual surveying}

Identifing and verifing the problem studies

\section{WQI Calculating}

There are many ways to calculate WQI such as NSF-WQI (USA), Bhargava (India), etc. and several ways based on or developed from these approaches. In this work, WQI was calculated in accordance with Decision No. 879 / QĐ-TCMT on the basis of 10 parameters of monitored data: $\mathrm{pH}$, Temperature $\left({ }^{\circ} \mathrm{C}\right)$, DO, COD, BOD5, TSS, N-NH ${ }^{4+}, \mathrm{P}_{-} \mathrm{PO}_{4}{ }^{3-}$ (mg/L), Turbidity (NTU), Coliform (MPN/100mL) - as a legal document for calculation and assessment of surface water quality in Vietnam. Table 1 shows the scale to assess water quality according to the WQI index. 
Table 1. Scale to assess water quality according to the WQI index

\begin{tabular}{|l|l|l|}
\hline Value of WQI & The level of water quality assessment & Colour \\
\hdashline $91-100$ & Used well for domestic water supply purposes & Blue \\
\hline $76-90$ & $\begin{array}{l}\text { Used for domestic water supply purposes, but need the appropriate treatment } \\
\text { measures }\end{array}$ & Green \\
\hline $51-75$ & Used for irrigation purposes and other similar purposes & Yellow \\
\hline $26-50$ & Used for water transportation and other similar purposes & Orange \\
\hline $0-25$ & Seriously polluted water, needing necessary measures to handle in the future & Red \\
\hline (Source: Water Quality Index Calculation Handbook - QĐ $879 /$ QĐ-TCMT) & \\
\hline
\end{tabular}

Method of calculating pollutant loads in domestic wastewater (Dom):

$$
\begin{gathered}
\mathbf{L}_{\mathbf{i}-\text { Dom }}=\mathbf{C}_{\mathbf{i}} \cdot \mathbf{Q}_{\text {waste }}=\mathbf{C}_{\mathbf{i}} \cdot \mathbf{Q}_{\text {supply }} \cdot \mathbf{K}_{\mathbf{h}}=\mathbf{C}_{\mathbf{i}} \cdot \mathbf{Q}_{\text {supply Dom }} \cdot\left(\mathbf{1}+\text { Rate by } \mathbf{Q}_{\text {supply Dom-service }}\right) \cdot \mathbf{K}_{\mathbf{h}} \\
\mathbf{Q}_{\text {supply Dom }}=\sum\left(\mathbf{K}_{\text {supply }} \cdot \mathbf{N}\right)
\end{gathered}
$$

Where: $\quad \mathrm{L}_{\mathrm{i} \text {-Dom}}$ : Load of i parameter in domestic wastewater (tons/year)

$\mathrm{C}_{\mathrm{i}}$ : The average concentration of the i parameter (tons/liters)

$\mathrm{Q}_{\text {supply: }}$ Water supply flow (liters/year); $\mathrm{Q}_{\text {waste }}$ : Wastewater flow (liters/year)

$K_{h}$ : The loss coefficient of wastewater compared to use water $\left(K_{h}=1\right)$

Rate by $\mathrm{Q}_{\text {supply Dom - service }}=0.1 ; \mathrm{N}$ : Population

$\mathrm{K}_{\text {supply: }}$ Domestic water supply per capita coefficient (liters/person.year)

Method of calculating pollutant loads in industrial wastewater (Ind):

$\mathbf{L}_{\mathbf{i}-I n \mathrm{~d}}=\mathbf{C}_{\mathbf{i}} \cdot \mathbf{Q}_{\text {Ind-waste }}$

Where: $\mathrm{L}_{\mathrm{i}-\mathrm{Ind}}$ : Load of i parameter in industrial wastewater (tons/year)

$\mathrm{Ci}$ : The average concentration of the i parameter (tons/liter)

$\mathrm{Q}_{\text {Ind-waste: Industrial wastewater flow (liters/year) }}$

For the industrial zones (IZs): $\mathbf{Q}_{I Z s-\text { waste }}=\mathbf{K}_{\mathbf{h}} \cdot \sum\left(\mathbf{T}_{\text {supply }} \mathbf{S}\right)$ )

Where: $\mathrm{T}_{\text {supply }}$ : Water supply standard for one unit IZ area $\left(\mathrm{m}^{3} / \mathrm{ha} /\right.$ day $)$

$\mathrm{S}$ : The manufacturing industrial land area (ha)

For small production facilities (Small): $\mathbf{Q}_{\text {Small-waste }}=\mathbf{K}_{\mathbf{h}} \cdot \sum\left(\mathbf{Q}_{\text {supply-Dom }} \cdot \boldsymbol{\alpha}\right)$

Where: $\mathrm{Q}_{\text {supply - Dom: Domestic water supply flow (liters/year) }}$

$\alpha$ : Conversion coefficient between domestic water supply and small production facilities' water supply

Kh: The loss coefficient of wastewater compared to use water $\left(\mathrm{K}_{\mathrm{h}}=0.8\right)$

Method of calculating pollutant loads in livestock wastewater (Liv):

$$
\mathbf{L}_{\mathbf{i}-L i v}=\mathbf{C}_{\mathbf{i}} \cdot \mathbf{Q}_{\text {Liv-waste }}=\mathbf{C}_{\mathbf{i}} \cdot \sum\left(\mathbf{K}_{\text {waste }} \cdot \mathbf{N} . \mathbf{T} / 12\right)
$$

Where: $\mathrm{L}_{\mathrm{i}-\mathrm{Liv}}$ : Load of i parameter in livestock wastewater (tons/year)

$\mathrm{C}_{\mathrm{i}}$ : The average concentration of the i parameter (tons/liter)

$\mathrm{Q}_{\text {Liv-wate: }}$ Livestock wastewater flow (liters/year)

$\mathrm{N}$ : The number of livestocks according to each local species

$\mathrm{T}$ : The average breeding period (months) 
$\mathrm{K}_{\text {waste }}$ : Wastewater emission coefficient for each of the species (liters/livestock.year)

Method of calculating pollutant loads in aquaculture wastewater (Aqua):

$$
\mathbf{L}_{\mathbf{i}-\text { - } q \text { qua }}=\boldsymbol{\Sigma}\left(\mathbf{N}_{\mathbf{j}} \mathbf{x} \mathbf{e}_{\mathbf{i j}-\text { Aver-waste }}\right)
$$

Where: $\mathrm{L}_{\mathrm{i} \text {-Aqua }}$ : Load of i parameter in aquaculture wastewater (tons/year)

$\mathrm{N}$ : Number of aquaculture according to each local $\mathrm{j}$ species

$\mathrm{e}_{\mathrm{ij}-\text { Aver-waste }}$ : Emission coefficient of i parameter for one species $\mathrm{j}$ (tons/year)

Method of calculating pollutant loads in rainwater runoff (Runoff):

$$
\begin{gathered}
\mathbf{L}_{\mathbf{i}-\text { Runoff }}=\mathbf{C}_{\mathbf{i}} \cdot \mathbf{Q}_{\text {Runof } f} 1 \\
\mathbf{Q}_{\text {Run } \mathrm{of} f}{ }^{2}=\text { c.i.A }
\end{gathered}
$$

Where: $\quad \mathrm{L}_{\mathrm{i} \text {-Runoff }}$ : Load of i parameter in Rainwater runoff (tons/year)

$\mathrm{C}_{\mathrm{i}}$ : The average concentration of the i parameter (tons/liter)

$\mathrm{Q}_{\text {Runoff }}^{1}$ : Rainwater runoff's flow (liters/year)

$\mathrm{Q}_{\text {Runoff }}^{2}$ : Rainwater runoff's flow $\left(\mathrm{ft}^{3} / \mathrm{s}\right)$

c: Runoff coefficient by Rational method (Agriculture land (Agri): c $=0.25$; Urban land (Urban): $c=0.53$, Industrial land (Ind): $c=0.18$ )

A: Runoff area (arce)

i: The average precipitation (in/h).

The pollutant loads scenarios

Table 2 presents pollutants' concentration and emission coefficient for each wastewater source, used for calculating pollutant loads. The pollutant loads scenarios arising in 2020 - 2030 are built respectively as follows:

The first Scenario - high emissions scenario: the concentration of pollutants remains unchanged in comparison with the current, denoted as $\mathrm{H}$.

The second Scenario - medium emissions scenario: the concentration of pollutants is treated in a certain way; accordingly, the current wastewater will be treated to meet the category B; denoted as B.

The third Scenario - low emission scenario: All wastewater is treated to meet the category A; denoted as A.

emissions scenarios are simplified; ${ }^{(* *)}$ : At the present, Dong Nai province has not published land use

\begin{tabular}{|c|c|c|c|c|c|c|c|c|c|c|c|c|}
\hline \multirow{3}{*}{$\begin{array}{l}\text { Parame } \\
\text { ter }\end{array}$} & \multicolumn{9}{|c|}{ Concentration of Pollutant (mg/L) } & \multirow{2}{*}{\multicolumn{3}{|c|}{$\begin{array}{c}\text { Emission Coefficient } \\
\text { (kg/ton/year) }\end{array}$}} \\
\hline & \multirow[b]{2}{*}{ Dom } & \multicolumn{2}{|c|}{ Ind } & \multicolumn{3}{|c|}{ Liv } & \multicolumn{3}{|c|}{ Runoff } & & & \\
\hline & & $\mathrm{IZs}$ & Small & Cattle & Pig & Poultry & Ind & Urban & Agri & $\begin{array}{l}\text { Intens } \\
\text { shrimp }\end{array}$ & $\begin{array}{l}\text { Improv } \\
\text { shrimp }\end{array}$ & $\begin{array}{l}\text { Othe } \\
\text { rs }\end{array}$ \\
\hline $\mathrm{BOD}_{5}$ & 206.6 & 180 & 35.72 & 1,543 & 712 & 86 & 17.3 & 79.9 & 28 & 32 & 137 & 4.5 \\
\hline COD & 404.2 & 320 & $\begin{array}{c}130.7 \\
2\end{array}$ & 2.200 & 1.968 & 103 & 125 & 99.4 & 51.1 & 62 & 278 & 15.9 \\
\hline
\end{tabular}
plan, so the assumption is no significant changes in the land use in the future.

Table 2. Synthesis of pollutants' concentration and emission coefficient

\section{Trang 252}


TạP CHÍ PHÁT TRIỂN KH\&CN, TậP 19, Số T6- 2016

\begin{tabular}{|c|c|c|c|c|c|c|c|c|c|c|c|c|}
\hline TSS & $\begin{array}{l}235.0 \\
\end{array}$ & 210 & $\begin{array}{c}149.0 \\
3\end{array}$ & 2,188 & 1,300 & 103 & 69 & 85 & 30 & 867 & 353.6 & 9.4 \\
\hline $\mathrm{TN}$ & 112.5 & 50 & 27.76 & 150.9 & 778.4 & 13.21 & $\begin{array}{c}1.17 \\
9\end{array}$ & 1.9 & $\begin{array}{c}0.96 \\
5\end{array}$ & 30 & 114 & 1.31 \\
\hline TP & 30 & 6 & 1.61 & 7 & 6.1 & 5.5 & \begin{tabular}{c|c}
0.20 & \\
1 &
\end{tabular} & $\begin{array}{c}0.38 \\
3\end{array}$ & $\begin{array}{c}0.12 \\
1\end{array}$ & 17 & 67 & 0.32 \\
\hline $\begin{array}{l}\text { Source } \\
\mathrm{s}\end{array}$ & {$\left[\begin{array}{l}15, \\
16]\end{array}\right.$} & {$[17,18$} & & [19] & & & \multicolumn{3}{|l|}{ [20] } & \multicolumn{3}{|l|}{$[12,14]$} \\
\hline $\begin{array}{c}\text { Scenari } \\
\text { o A }\end{array}$ & $\begin{array}{c}\text { Colu } \\
\text { mn A } \\
\text { QCV } \\
\mathrm{N} \\
14: 20 \\
08\end{array}$ & \multicolumn{2}{|c|}{$\begin{array}{c}\text { Column A } \\
\text { QVCN } \\
40: 2011\end{array}$} & \multicolumn{3}{|c|}{$\begin{array}{c}\text { Column A QVCN 01- } \\
79: 2011\end{array}$} & \multirow{2}{*}{\multicolumn{3}{|c|}{$\begin{array}{c}\text { Assuming } \\
\text { pollutants' } \\
\text { concentration, land } \\
\text { area and } \\
\text { precipitation as }^{(* *)} \\
\text { current }^{\left({ }^{*}\right)}\end{array}$}} & \multirow{2}{*}{\multicolumn{3}{|c|}{$\begin{array}{l}\text { Using emission coefficient } \\
\text { as current }{ }^{(*)}\end{array}$}} \\
\hline $\begin{array}{l}\text { Scenari } \\
\text { o B }\end{array}$ & $\begin{array}{c}\text { Colu } \\
\text { mn B } \\
\text { QCV } \\
\text { N } \\
14: 20 \\
08\end{array}$ & $\begin{array}{r}\text { Colt } \\
\text { Q } \\
40:\end{array}$ & $\begin{array}{l}\mathrm{nn} \mathrm{B} \\
\mathrm{CN} \\
011\end{array}$ & \multicolumn{3}{|c|}{$\begin{array}{c}\text { Column B QVCN 01- } \\
79: 2011\end{array}$} & & & & & & \\
\hline
\end{tabular}

\section{RESULTS AND DISCUSSION}

Assessing changes in surface water quality on the main rivers in Dong Nai province

The changing trend in surface water quality seemed relatively similar over the years (20102014). Besides, the water quality fluctuated significantly seasonally: water quality in the dry season was better than that in the rainy season; the water quality differences between the two seasons can be seen clearly in 1 and 4 segments of the Dong Nai river (Fig. 2).

The first segment of Dong Nai river (SW-DN01-02) is a receive-water area from DakLua and DakTop streams (Lam Dong), has a stable annual water quality affected by seasons. Water quality in the dry season reached good to very good level and ranged poor to very poor in the rainy season, caused by the increasing concentration of pollutants, notably the TSS (double the standards), turbidity, microorganisms (E. Coli), Fe, etc. Similar to the $1^{\text {st }}$ segment, water quality in the second segment (Vinh Cuu district - SW-DN-03$06)$ is clearly distinguished between dry and rainy seasons: water quality in the dry season fluctuated around the very good level and; therefore, suited for household water supply, but was in the downward tendency (to good level) in the rainy season due to the increase of turbidity, TSS, and microorganisms. It could be explained by large amounts of silt and nutrients from upstream water flowing down in the rainy season. The third segment flows through Bien Hoa city (from Hoa An bridge to Dong Nai bridge - SW-DN-07- 15) has an important role in water supply. However, water quality here was not good, even declining, especially in the rainy season. Water quality in San Mau stream - Cai River and Linh stream - Cai River only met irrigation purposes and other similar purposes, requiring a treatment. The fourth segment (from the confluence of Buong - Dong Nai river to the confluence of Sai Gon - Dong Nai river - SW-DN-16-19) received industrial and household wastewater, and also be affected by tidal forces. Water quality here generally seemed quite good: good in the dry season and medium in the rainy season. 

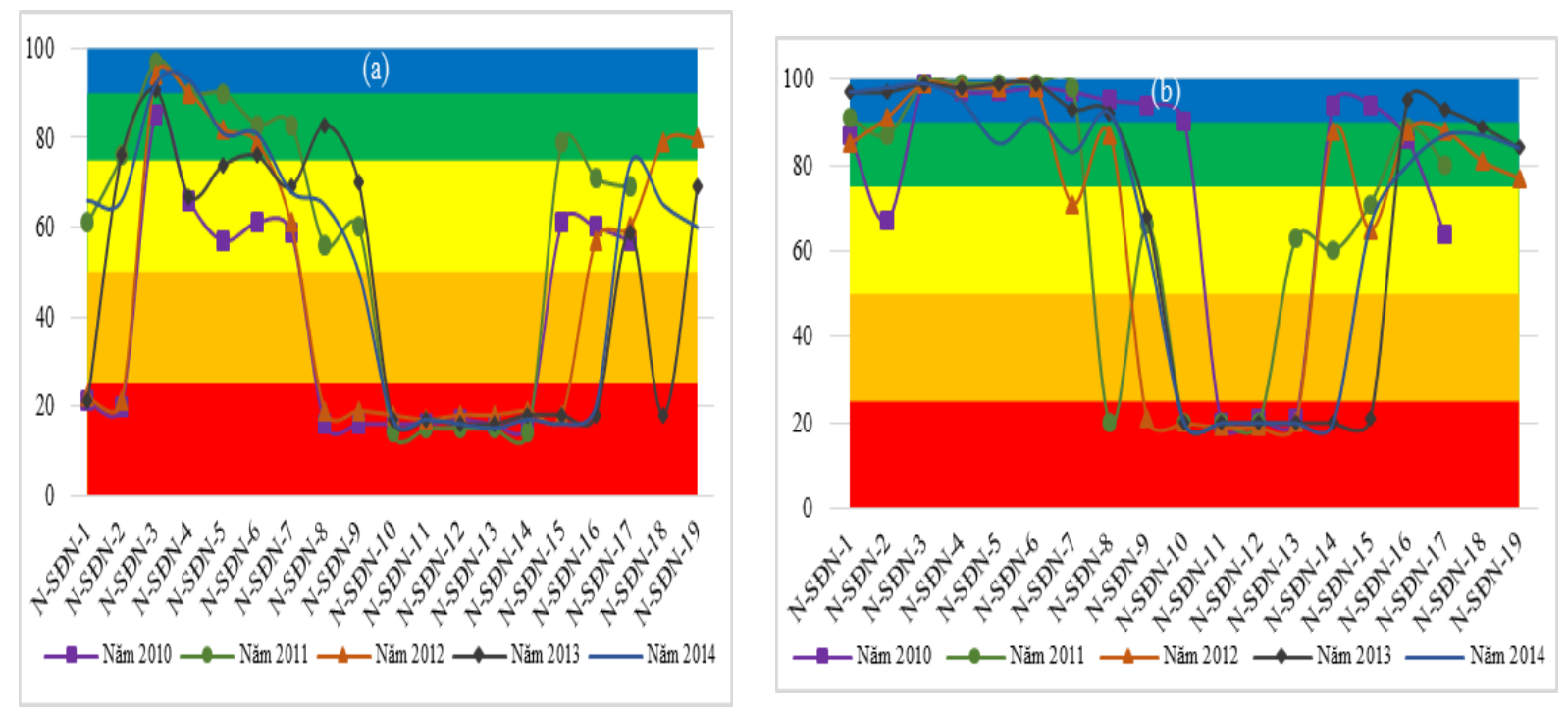

Fig. 2. The changes in surface water quality (according WQI) of Dong Nai River (2010-2014): The rainy season; (b) The dry season

\section{Calculating and forecasting pollutant load in Dong Nai province}

Pollutant loads calculation results in 2013 by administrative units and by source of waste is presented in Figure 3 and Table 3, respectively. Pollutant loads in Nhon Trach, Vinh Cuu, Tan Phu, Dinh Quan, Xuan Loc districts and Bien Hoa city hit the highest records of the 11 administrative units in 2013 (Fig. 3). Vinh Cuu, Tan Phu, Dinh Quan, Xuan Loc district emitted a huge COD, BOD5, TSS loads, accounted for nearly $47 \%$; TN and TP loads were approximately $36 \%$ of total loads of Dong Nai. The main cause was the rainfall runoff.

Pollutant loads in Nhon Trach district and Bien Hoa City also contained a large number of COD, BOD5 and TSS loads (average about $20 \%$ ), mainly from local household and industrial activities. Bien Hoa city was the area having the highest TN and TP emission (more than $24 \%$ and $35 \%$ of total local loads, respectively).

Among the five sources (Table 3), runoff (natural source) contributed a largest number of loads: BOD5, COD and TSS accounted for nearly $90 \%$ of total loads; TN and TP were about $43 \%$. Domestic wastewater had high BOD5, TSS, TN and TP loads. Industrial wastewater emitted less of loads, approximately $6 \%$ loads of artificial sources. Livestock wastewater's TN loads was nearly $40 \%$ of TN from artificial sources; BOD5 and TSS fluctuated about $25 \%$; COD nearly $15 \%$. Although aquaculture contributes a small percentage of economic structure, COD loads were huge, especially COD. 


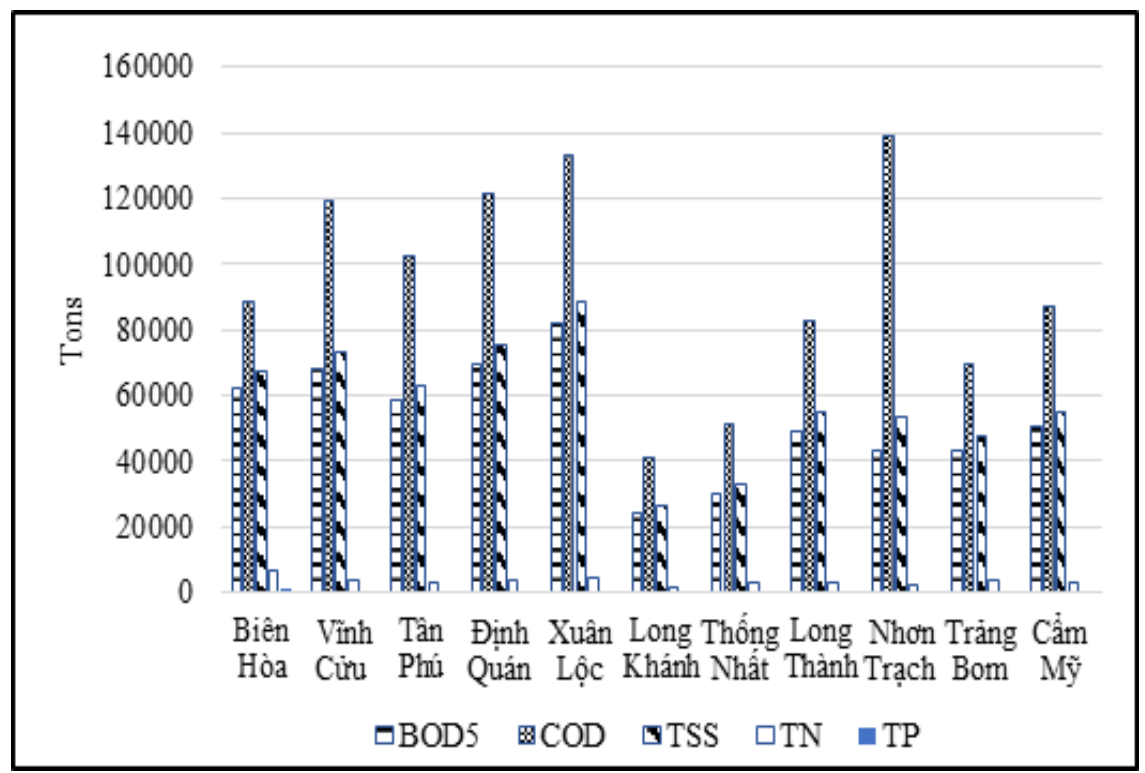

Fig. 3. Pollutant loads of Dong Nai province in 2013 by administrative units

Table 3. Pollutant loads of Dong Nai province in 2013 by source of waste (Unit: tons/year)

\begin{tabular}{|l|c|c|c|c|c|}
\hline & BOD $_{5}$ & COD & TSS & TN & TP \\
\hline Domestic & 21,514 & 42,090 & 24,471 & 11,715 & 3,124 \\
\hline Industrial & 2,703 & 5,709 & 4,240 & 1,098 & 148 \\
\hline Livestock & 8,444 & 21,838 & 15,166 & 8,151 & 126 \\
\hline Aquaculture & 493 & 76,043 & 9,144 & 344 & 183 \\
\hline Rainwater runoff & 548,417 & 889,724 & 586,132 & 16,859 & 2,459 \\
\hline Total & 581,571 & $1,035,403$ & 639,153 & 38,167 & 6,040 \\
\hline
\end{tabular}

Pollutant emission scenarios in the period 2020-2030 were calculated and presented in Figure 4. The differences between $\mathrm{H}$ scenario and B scenario in 2020 are: BOD5, COD, TSS loads are higher nearly $8 \%$ and TN, TP are about $50 \%$. By 2030, TN loads of B scenario falls approximately $57 \%$; BOD5, COD and TSS decline more $11 \%$ compared to $\mathrm{H}$ scenario. However, pollutant loads of $\mathrm{B}$ and $\mathrm{A}$ scenarios are not greatly different ( $<5 \%$ for BOD5, COD, TSS loads and about 10-15\% for TN and TP loads). Analyzing the results of pollutant loads calculation and current surface water quality in Dong Nai River, some notable points are shown as follows:

The $1^{\text {st }}$ segment of Dong Nai river and its tributaries: flowing through Tan Phu and Dinh Quan districts. In 2013, TSS loads of 2 areas was about 140.000 tons, COD was nearly 220.000 tons, and BOD5 was over 130.000 tons - in which runoff source emitted more $95 \%$ of the total loads. The amount of rainfall from May to Oct ranged approximately from 1500 to $2000 \mathrm{~mm}$, made water levels in rivers and streams rise; washed off rock and soil; increased concentrations of TSS and mud, etc.

The $2^{\text {nd }}$ segment of Dong Nai river and its tributaries (flowing through Vinh Cuu district): Similar to the $1^{\text {st }}$ segment, this area is sparse population, economic and production activities are trivial. Thereby, the main pollutant loads come from runoff source. The content of TSS, turbidity, Coliform raised in rainy season is the cause making local water quality decline. 
The $3^{\text {rd }}$ segment of Dong Nai river and its tributaries (flowing through Bien Hoa city): receiving almost wastewater from urban and industrial activities of Bien Hoa city via rivers, streams and sewers, etc. Besides rainwater runoff, Bien Hoa city also contributed significant pollutant loads from household and industrial activities (average loads were $40 \%$ of the total loads of 2 sources in Dong Nai). This is the main cause making concentrations of nutrients and microorganisms appear in the whole year.

The $4^{\text {th }}$ segment of Dong Nai River and its tributaries (flowing through Long Thanh - Nhon
Trach district): The reasons that made concentrations of TSS, microorganisms and nutrients arise in water were local wastewater and nearby localities' influence, such as household and industry sources in Nhon Trach, Long Thanh, Bien Hoa (in which, total loads of industrial wastewater accounted for nearly $80 \%$ of total loads of industrial activities in Dong Nai); livestock wastewater in this segment and Trang Bom, Cam My districts were the areas which had loads of livestock source contributed approximately $30 \%$ of the total loads of Dong Nai province, respectively.

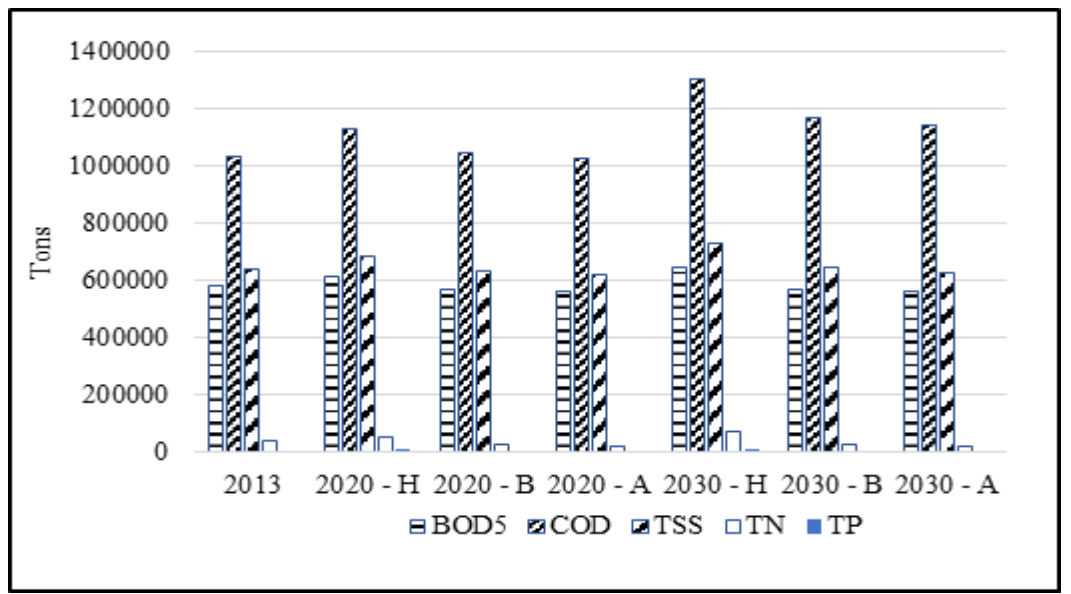

Fig. 4. The pollutant loads of Dong Nai Province in the period $2013-2020-2030$

\section{CONCLUSION}

The quality of surface water in the main rivers of Dong Nai province in the period 2010 - 2014 improved significantly during the dry season but tends to decline during the rainy season with presence mainly of TSS, turbidity and coliform, etc. The 2 nd segment of Dong Nai river had the highest water quality, conversely, the 3rd segment and its tributaries in Bien Hoa city have the worst quality, especially in San Mau stream - Cai river and Linh stream - Cai river.

Regarding pollutant loads, besides natural sources (rainwater runoff), household, livestock and aquaculture are various artificial sources contributing most loads. In 2013, pollutant loads from industrial and household activities in Bien Hoa city accounted for a large proportion (40\% each source); livestock activities developed in Xuan Loc district (nearly $20 \%$ ); aquaculture activities in Nhon Trach district contributed more than $75 \%$ of the corresponding total loads in Dong Nai. In the period 2020 - 2030, pollutant loads of household, aquaculture and livestock will increase and create pressure on the quality of the local environment, particularly the $3^{\text {rd }}$ and $4^{\text {th }}$ segments of Dong Nai river, requiring appropriate management and attention.

\section{Trang 256}




\section{Đánh giá diễn biến chất lượng nước mặt và tải lượng ô nhiễm tại tỉnh Đồng Nai}

\section{- Bùi Thị Diễm Hương}

Viện Khí tượng Thủy văn Hải văn và Môi trường

\section{- Lê Ngọc Tuấn}

Trường Đại học Khoa học Tự nhiên, ĐHQG-HCM

\section{TÓM TẮT}

Nghiên cứu nhằm mục tiêu đánh giá diễn biến chất luợng nuớc mặt tỉnh Đồng Nai giai đoạn 2010 - 2014. Bên cạnh đó, tải luợng ô nhiếm tù các nguồn thải được tính toán đến năm 2020, 2030 vói 03 kịch bản xủ lý nuóo thải khác nhau - phục vu kiện toàn công tác quản lý môi truòng tại địa phuoong. Kết quả đánh giá theo chi số chất lương nước (WQI) cho thấy, trong 5 năm gần đây, chất lượng nước mặt ở tỉnh Đồng Nai dần được cải thiện vào mùa khô nhung suy giảm đáng kể vào mùa mura do hàm luợng cao các chất rắn lo lưng, sắt và vi sinh - nhất là đoạn sông Đồng Nai 3 chảy qua thành phố Biên Hòa. Hiện trạng này liên quan nhất định đến tải lương ô nhiễm tù các nguồn thải trên địa bàn. Tải lương ô nhiếm tì hai nguồn sinh hoạt và công nghiệp của TP Biên Hòa hiện chiếm tỷ trọng lón (40\% mỗi nguồn); hoạt động chăn nuôi phát triển nhất tại huyện Xuân Lộc - chiếm khoảng $20 \%$; hoạt động nuôi trồng thủy sản tại huyện Nhơn Trạch đóng góp hơn $75 \%$ tổng tải luợng tuong úng của toàn tỉnh... trong đó, tải lương BOD5, COD và TSS rất lón -tuoong ưng 581.570 tấn, 1.035 .403 tấn và 639.153 tân/năm, có chiều hướng gia tăng trong tương lai - đòi hỏi phải có biện pháp quản lý thich hợp.

Tù khóa: tải luợng ô nhiếm, nước mặt, chất lượng nước, chi số chất lương nước

\section{REFERENCES}

[1]. S.E. Cooke, S.M. Ahmed, N.D. MacAlpine, Introductory guide to surface water quality monitoring in agriculture. Conservation and development branch, Alberta Agriculture, Food and Rural Development. Edmonton, Alberta, Australia (2000).

[2]. T. Le, Research zoning of water quality according to the Water Quality Index (WQI) and assessing the ability to use of the water from rivers and canals in HCM City, Department of Science and Technology, Ho Chi Minh city (2006).

[3]. T.L. Ton, Developing quality index to assess and manage the water quality of Dong Nai river system, University of Environment and Resources, Ho Chi Minh city (2007).

[4]. Mekong River Commission, The Mekong river card on water quality,2, December 2009 - An assessment of potential Human Impacts to Mekong River water quality (2009).

[5]. T.M.H. Pham, Development of water quality indices for surface water quality evaluation in Vietnam, PhD Thesis (2010).

[6]. O.S. Fatoki, P. Gogwana, A.O. Ogunfowokan, Pollution assessment in the Keiskamma River and in the impoundment downstream. African Journals, 29, 2 (2003).

[7]. O.E. Essien,The Effect of Anthropogenic Pollution Loads Along Ikpa River Tributary Under Urbanization Expansion, Journal of Applied Sciences in Environmental Sanitation, 5, 273-282 (2010).

[8]. Y. Deng, Z. Binghui, F. Goo, L. Kun, I. Zicheng, The study on the total water pollutant Load allocation in the Changiiang (Yangtze River) estuary and adjacent seawater area. 
Estuarine, Coastal and shelf Science, 86, 331336 (2010).

[9]. T.D. Thanh, T.V. Minh, C.T.T. Trang, V.D. Vinh, T.A. Tu, The loads capacity of Halong Bay - Bai Tu Long. Publishing house: Natural Sciences and Technology, Hanoi (2012).

[10]. T.T.T. Cao, D.T. Tran, X.S. Le, Assessing pollutant loads brought into Tam Giang - Cau Hai and prediction to 2020, Journal of Marine Science and Technology, 13, 276-283 (2013).

[11]. C.T.T. Trang, N.T.P. Hoa, Assessing pollutant loads capacity in the coastal water of the Cat $\mathrm{Ba}$ Island to serve sustainable development. Institute of Marine Environment and Resources, Hai Phong city (2009).

[12]. N.K. Phung, Assessing loads capacity of Vinh Long Rivers, canals system and land. Department of Science and Technology, Vinh Long province (2011).

[13]. N.T. Le, X.H. Tran, T.M.T. Nguyen, X.T. Nguyen, M.L, Nguyen, The current status of surface water and wastewater receiving capacity of Ben Luc river, Ben Luc - Long An, Journal of Science and Technology Development, 10, 6-8 (2012a).

[14]. N.T. Le, B.C. Tran, N.H.P. Vu, Calculating pollutant loads by the shrimp farming in Cai
Nuoc district - Ca Mau. Journal of Science and Technology Development, 15, 29-45 (2012b).

[15]. Department of Natural Resources and Environment, Dong Nai province The general environmental protection project in Dong Nai river basin of Dong Nai province to 2010 and towards 2020 (2009).

[16]. People's Committees of Binh Duong, Guidelines handbook to collect, calculate environmental indicators in the province of Binh Duong the period 2013 - 2020 - Attached to Decision 88/2014/QĐ - People's Committees of Binh Duong (2014).

[17]. Institute of Natural Resources and Environment The statistical survey and establish a list of pollutant sources on Saigon - Dong Nai river basin systems (Stage 1), Final Report of Environment Agency's mission (2005).

[18]. Department of Natural Resources and Environment, Dong Nai province 2013, Report on environmental planning of Dong Nai province in (2013).

[19]. Department of Natural Resources and Environment, Binh Dinh province, Agricultural hydraulic plan of Binh Dinh to 2020 (2010). 